\title{
Article \\ Efficacy of New Local Bacterial Agents against Pyrenophora tritici-repentis in Kuban Region, Russia
}

\author{
Anzhela Asaturova *, Natalya Zhevnova, Natalya Tomashevich (D), Marina Pavlova, Oksana Kremneva (D), \\ Galina Volkova and Nikita Sidorov
}

check for updates

Citation: Asaturova, A.; Zhevnova, N.; Tomashevich, N.; Pavlova, M.; Kremneva, O.; Volkova, G.; Sidorov N. Efficacy of New Local Bacterial Agents against

Pyrenophora tritici-repentis in Kuban Region, Russia. Agronomy 2022, 12, 373. https://doi.org/10.3390/ agronomy 12020373

Academic Editor: David Correa-Galeote

Received: 2 December 2021 Accepted: 29 January 2022 Published: 1 February 2022

Publisher's Note: MDPI stays neutral with regard to jurisdictional claims in published maps and institutional affiliations.

Copyright: (C) 2022 by the authors. Licensee MDPI, Basel, Switzerland. This article is an open access article distributed under the terms and conditions of the Creative Commons Attribution (CC BY) license (https:// creativecommons.org/licenses/by/ $4.0 /)$
Federal Research Center of Biological Plant Protection, 350039 Krasnodar, Russia; nataliaznevnova@gmail.com (N.Z.); nataliatomashevich@yandex.ru (N.T.); fridaamely@yandex.ru (M.P.); kremenoks@mail.ru (O.K.); galvol.bpp@yandex.ru (G.V.); elisitor@mail.ru (N.S.)

* Correspondence: tiamat-7@mail.ru; Tel.: +7-9180801572

\begin{abstract}
The phytopathogenic fungus Pyrenophora tritici-repentis is a causal agent of tan spot. Antagonistic microorganisms can be used as a non-chemical alternative treatment against the tan spot of wheat. Bacillus velezensis BZR $336 \mathrm{~g}$ and BZR 517 stains were selected as the most active microorganisms and potential biocontrol agents. We found that B. velezensis strains BZR $336 \mathrm{~g}$ and BZR 517 exhibited antagonistic activity against $P$. tritici-repentis $\mathrm{Kr}-15 / 2016$ in vitro: they inhibited mycelium growth by $72.4-94.3 \%$ and caused its degenerative changes. Treatment of seeds and plants with strains BZR $336 \mathrm{~g}$ and BZR 517 provided a biological efficiency of 31.2-38.4\% against tan spot, while artificial inoculation of plants provided only $28.4-43.8 \%$ biological efficiency. Treatment of seeds and plants with BZR $336 \mathrm{~g}$ and BZR 517 in a three-year field trial demonstrated $24.6-50 \%$ biological efficiency. BZR $336 \mathrm{~g}$ and BZR 517 provided 5.0-7.6\% additional yield. We conclude that BZR $336 \mathrm{~g}$ and BZR 517 are promising options for novel bioproducts that can control P. tritici-repentis tan spot.
\end{abstract}

Keywords: Bacillus velezensis; Pyrenophora tritici-repentis; biological plant protection; tan spot; winter wheat; microbial strains

\section{Introduction}

Tan spot, also known as yellow leaf spot, is one of the major diseases of winter wheat (Triticum aestivum L.) and is caused by the fungal pathogen Pyrenophora tritici-repentis (Died.) Drechs (anamorph of Drechslera tritici-repentis (Died.). This pythopathogen attacks wheat leaves causing necrotic lesions and chlorotic spots. Consequently, the plant photosynthetic area decreases, resulting in leaf death and, finally, in reduced leaf quality [1,2]. Yield losses can reach up to $50 \%$ [3].

Tan spot occurs worldwide in all major wheat growing regions [4]. The disease has been documented in Syria, Argentina, Brazil, Algeria, the USA, Canada, Russia and some other countries [2,5-8].

Key factors of its occurrence include minimal tillage and short crop rotation [8-10], continuous wheat cropping and the use of susceptible varieties [1,11], as well as excessive use of chemical pesticides [10,11]. Populations of $P$. tritici-repentis have a high genetic diversity, which positively affects the host range and virulence [12]. P. tritici-repentis conidia can survive for a long time on plant debris and spread over large distances [5].

In Russia, tan spot was identified in 1985 in the North Caucasus and subsequently spread throughout the country. Today, this problem remains relevant for the Kuban Region (Northern Caucasus, Russia), where wheat is the main cultivated crop, and farmers seek to reduce the number of chemical treatments. In recent years, this disease has seriously affected wheat production in terms of quantity and quality $[10,13]$.

The strategy of combating tan spot disease is complex and consists of a combination of chemical, cultural, genetic, and sometimes biological control measures [1]. Currently, chemical pesticides are mainly used. However, they negatively affect the environment and 
human and animal health [8]. The overuse of fungicides can make the fungicide pathogenresistant $[7,14]$. Moreover, sometimes chemicals are not effective against $P$. tritici-repentis [15]. Eco friendly plant growth-promoting rhizobacteria (PGPR) and biopreparations based on them are an alternative to chemical fungicides. Numerous reports show that PGPRs are effective biocontrol agents that reduce plant diseases and can directly or indirectly stimulate plant growth and development $[6,10,11,16]$.

Bacteria from the Bacillus group are effective bioagents against fungal plant pathogens. Bacteria influence many growth- and immunity- related metabolic processes in the plant. Bacillus can produce lots of secondary metabolites of various chemical natures. This determines their suppressive properties in relation to a wide list of phytopathogens. Cyclic lipopeptides play a key role in the induction of plant immunity due to microorganisms. These substances provide protection against a wide range of pathogens through antagonistic and/or induced resistance effects [17].

B. velezensis produces a large number of antimicrobial metabolites: lipopeptides, polypeptides, enzymes, and non-peptide compounds [3-7]. The mechanism of action (MOA) of lipopeptides on filamentous fungi is associated with their effect on membranes through interaction with ergosterol. As a result, pores are formed, followed by the release of monovalent cations from the cells, which leads to lysis.

$B$. velezensis strains associated with winter wheat plants may be of interest as biological agents for tan spot control and increasing crop yields. The bacteria have been proven to be effective on various crops and in different climate regions. B. velezensis showed great antagonist activity in the south of Russia [18], as well as in the extreme weather of Western Siberia $[19,20]$. These microorganisms promote plant growth [21], making them excellent candidates for the development of the new bioproducts.

Data analysis of the literature shows insufficient information on the effectiveness of bacteria of the genus Bacillus against tan spot. Thus, in sustainable agriculture, there is a timely need for promising strains of microorganisms, along with the development of microbial based biocontrol agents against tan spot. The use of PGPRs and other microbialbased products is relevant for agriculture, especially for organic farming, where the use of chemical pesticides is prohibited.

In this research, we aim to study the interaction mechanism of Bacillus biocontrol strains with a tan spot pathogen ( $P$. tritici-repentis), as well as to study the biological effectiveness of environmentally friendly microbiological agents under conditions of natural infection.

\section{Materials and Methods}

\subsection{Bacterial and Fungal Strains}

In the research we used two initial strains of Bacillus isolated from the rhizosphere of winter wheat in Krasnodar (Kuban Region, Krylovsk district 46 $6^{\circ} 19^{\prime} 19^{\prime \prime}$ N $39^{\circ} 57^{\prime} 51^{\prime \prime}$ E; Pavlovsky district $46^{\circ} 08^{\prime} 22^{\prime \prime} \mathrm{N} 39^{\circ} 47^{\prime} 19^{\prime \prime}$ E).

Through genome sequencing of these strains, we identified their taxonomic position. Comparative bioinformation analysis resulted in the collection and deposition of two genomes into NCBI database: B. velezensis BZR 336 g_n (Assembly: GCA_009683125.1, GenBank: NZ_WKKU00000000.1) and B. velezensis BZR 517_n (Assembly: GCA_009683155).1, GenBank: NZ_WKKV00000000.1) [21,22].

The plants were inoculated with the $P$. tritici-repentis isolate $\mathrm{Kr}-15 / 2016$ recovered from the susceptible winter wheat variety Batko. The P. tritici-repentis $\mathrm{Kr}-15 / 2016$ isolate was typed to race 8 based on its ability to induce necrosis and chlorosis in cv. Glenlea and the 6B365 and 6B662 lines [23]. This isolate produces three toxins: Ptr ToxA, Ptr ToxC, or Ptr ToxB [24,25]. We chose this race because it produces all three known toxins and is widespread in Krasnodar Krai [26].

Strains of bacteria and fungi belong to the unique scientific facility State Collection of Entomoacariphages and Microorganisms of the Federal Scientific Center for Biological Plant Protection, Krasnodar, Russia (http:/ /ckp-rf.ru/ no. 585858, accessed on 2 December 
2021). Biocontrol strains have passed toxicological and hygienic examination at the Center for Toxicology and Hygienic Regulation of Biopreparations (Serpukhov, Russia). In the research we used the Unique Scientific Database «Technological line for obtaining microbiological plant protection products of a new generation» (https:/ / ckp-rf.ru/usu/671367/ accessed on 2 December 2021) of the Federal Scientific Center for Biological Plant Protection, Krasnodar, Russia.

For each experiment, fresh liquid cultures were prepared on the original optimized nutrient medium in New Brunswick Scientific Excella E25 (Enfield, USA) shaker-incubators (180 rpm). The initially optimized culture medium was obtained with a modified Czapek medium containing corn extract (nitrogen source) and molasses (carbon source). The incubation period of the BZR $336 \mathrm{~g}$ strain was $48 \mathrm{~h}$ at $25^{\circ} \mathrm{C}$; BZR 517 strain-36 h at $30^{\circ} \mathrm{C}$ [26].

\subsection{Laboratory Experiments}

Antagonistic activity was examined with the dual cultures method on optimized culture media [27]. We placed mycelial agar blocks in Petri dishes (PD), while the bacterial strain was applied by the stroke method at a distance of $6 \mathrm{~cm}$ from the pathogen block. The cultures were then incubated for 20 days at $28.0^{\circ} \mathrm{C}$. Pure pathogen fungal cultures and bacteria seeded separately are used as controls.

The counts were carried out on the fifth and fifteenth days. The degree of fungal mycelium inhibition was calculated by the following formula [28]:

$$
\mathrm{I}, \%=(\mathrm{Dc}-\mathrm{Dt}) / \mathrm{Dc} \times 100
$$

where Dc is the diameter of fungal colony in the control, and Dt is the diameter of fungal colony in the dual culture.

We examined bacterial-fungal interactions with a Zeiss AxioScope A1 microscope (Carl Zeiss, Oberkochen, Germany). When filling an optimized culture media in PDs, the bacterial culture was placed on a glass slide on one side, and P. tritici-repentis mycelium on the other. PDs then were incubated at $24-26^{\circ} \mathrm{C}$ under light. The slides were not stained [29].

We observed the pathogen-antagonist system, as well as length and diameter measurements of mycelium segments with a Carl Zeiss AxioVision Rel. 4.8.2 (Carl Zeiss, Moscow, Rusia) software in dynamics on the third, seventh, tenth and fourteenth days of co-cultivation.

\subsection{Growth Chamber Assay}

We sought to determine the effect of pre-sowing treatment with bio-agents on the resistance of winter wheat plants to $P$. tritici-repentis $\mathrm{Kr}-15 / 2016$, despite the fact that $\tan$ is an aerogenic infection. Consequently, we provided for two variants of the experiment: (1) presowing treatment followed by the treatment of vegetative plants; (2) treatment of vegetative plants. In the experiment, seeds of soft winter wheat variety Batko were used. This variety is highly susceptible to tan spot-the incidence rate is up to $60 \%$.

The experiment consisted of four stages: presowing treatment (or sowing grain without treatment), first treatment of vegetative plants, pathogen suspension inoculation, second treatment of vegetative plants (Figure 1 ).

It is common to use $\mathrm{V}-8$ juice to grow fungi. It is a blend of 8 vegetable juices. This mixture is not produced in Russia. Therefore, we used a V-4 nutrient medium, consisting of a 15\% mixture of vegetable juices in a ratio of 4:3:2:1 of beetroot, parsley or celery, carrot and tomato juices, respectively, at $0.3 \% \mathrm{CaCO}_{3}, 2 \%$ agar. This nutrient medium contributes to the abundant sporulation of the fungus. 


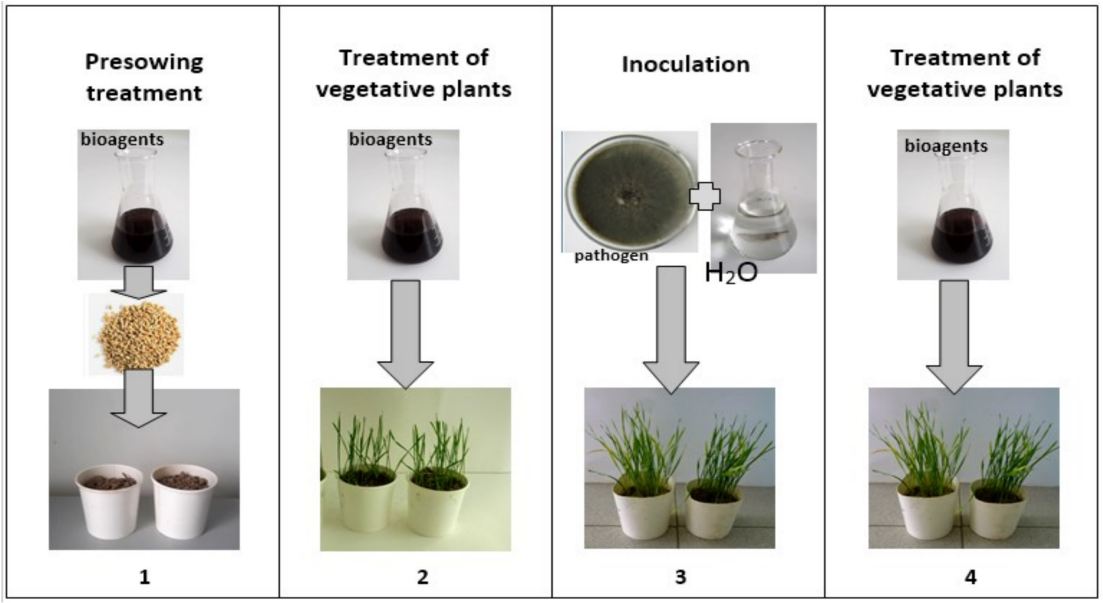

Figure 1. Stages experiment in climate chamber.

The fungus was grown on V-4 solid nutrient medium for three days at $25^{\circ} \mathrm{C}$. The culture was then exposed to UV for five days to stimulate the formation of conidiophores. Then the fungus was placed in a refrigerator for one day to form conidia. A pure culture of the spore fungus $P$. tritici-repentis $\mathrm{Kr}-15 / 2016$ was used on a solid nutrient medium nine days old to prepare a water-conidial suspension. Mycelium of fungi was scraped off the surface of the nutrient medium. We homogenized mycelium papillae in $100 \mathrm{~mL}$ of sterile distilled water to obtain fungal spore suspensions. Conidia number per unit was counted in the Goryaev chamber. The final spore suspension concentration was $3-5 \times 10^{3}$ spores $/ \mathrm{mL}$; the infectious load was $50 \mathrm{~mL} / \mathrm{m}^{2}$ [26]. Our experimental research determined that this concentration promotes the optimal level of infection.

Seeds were sown in glasses with sand. There were 30 seeds in one glass. All experiments were performed in triplicate. Plants were germinated in a climatic chamber (Binder KBWF, Tuttlingen, Germany) at a temperature of $25^{\circ} \mathrm{C}$, illumination of 14,000 lux, and humidity of $40 \%$ for six days until the double leaf phase and then were infected with a pathogen.

Before inoculation, we carefully removed the epicuticular wax coating from the surface of the leaves and treated them with a water-conidial suspension of the fungus $P$. tritici-repentis $\mathrm{Kr}$ $15 / 2016$ using a spray gun. The removal of epicuticular wax from the leaf surface facilitates better penetration of the pathogen into the plant. By artificially stimulating the adaptive immune defenses we aim to get more pronounced disease symptoms. The infected plants were incubated for $16 \mathrm{~h}$ at $100 \%$ humidity and $20^{\circ} \mathrm{C}$ in the dark.

After inoculation, the plants were grown in a climate chamber at $25^{\circ} \mathrm{C}, 14,000$ lux illumination, and $40 \%$ humidity for five days. Watering was done as needed. Vegetative plants were treated with laboratory samples of the liquid cultures twice: the first was on the third day after sowing; and (2) three days after inoculation. The fungus had already penetrated the plant and/or started to develop during the second treatment. Still, we wanted to establish whether the disease was curable at this stage.

The pesticide Raxil, KS B (Bayer, Moscow, Russia) was used as a chemical standard for seed treatment (tebuconazole, $60 \mathrm{~g} / \mathrm{L}$, application rate $0.45 \mathrm{~L} / \mathrm{t}$ ); Alto Super, KS (propiconasol, $250 \mathrm{~g} / \mathrm{L}$, cyproconazole, $80 \mathrm{~g}$ ) (Syngenta, Moscow, Russia) was used for the treatment of vegetative plants (application rate $0.45 \mathrm{~L} / \mathrm{ha}$ ). In the control, seeds and plants were treated with distilled water.

In this research, we determined biological efficacy by two criteria: the number of infection points and the type of sustainability. This is the type of sustainability determined by the method of Rees et al. [30]. This scale takes into account the size and type of lesions (Table 1). 
Table 1. Scale for assessing the resistance of wheat varieties to the yellow leaf spot pathogen in the seedling phase (Rees, Platz, 1987).

\begin{tabular}{lcc}
\hline Size and Type of Lesion & Reaction Type, Point & Wheat Phenotype \\
\hline No symptoms & 0 & $\mathrm{HR}$ \\
\hline $\begin{array}{l}\text { Small (up to } 0.5 \mathrm{~mm} \text { ) dark brown spots. } \\
\text { There are no chlorosis or they are small }\end{array}$ & 1 & $\mathrm{R}$ \\
\hline $\begin{array}{l}\text { Dark brown spots up to } 1 \mathrm{~mm} \text {. There may } \\
\text { be chlorosis. }\end{array}$ & 2 & $\mathrm{MR}$ \\
\hline $\begin{array}{l}\text { Small spots (1-2 mm) from pale to dark } \\
\text { brown, often with a yellow halo }\end{array}$ & 3 & $\mathrm{MS}$ \\
\hline $\begin{array}{l}\text { Large (3 mm) brown spots, usually with a } \\
\text { dark brown center. Mostly surrounded by } \\
\text { significant chlorosis from 2 to 3 mm. }\end{array}$ & 4 & $\mathrm{~S}$ \\
\hline $\begin{array}{l}\text { Large (3-5 mm) necrosis with a dark brown } \\
\text { center, severe yellowing of the surrounding } \\
\text { tissues. The spots coalesce, resulting in the } \\
\text { death of part or all of the leaf. }\end{array}$ & 5 & $\mathrm{HS}$ \\
$\begin{array}{l}\text { Note. HR-high resistance, R-resistance, MR-medium resistance, MS-medium susceptibility, S-susceptibility, } \\
\text { HS-high susceptibility. }\end{array}$ &
\end{tabular}

The number of infection points shows the ability of a bioagent to inhibit the penetration of a pathogen into a plant, and the type of sustainability shows the ability of a bioagent to restrain the development of the infection that has already penetrated into plant tissue.

We applied Abbott's formula to distinguish biological efficiency by the number of foci of infection and the type of resistance [31]:

$$
\mathrm{BE}=(100 \times(\mathrm{P}-\mathrm{p})) / \mathrm{P},
$$

BE-biological efficiency, \%; P-infection intensity in the control, \%; p-infection intensity with treatment, $\%$.

\subsection{Field Trials}

Field trials were held in 2013-2016 on the experimental plots of the Federal Scientific Center for Biological Plant Protection (Russia, Krasnodar, 45 02'57.2" N 38 52'29.7" E) under natural field conditions. Sunflower was a test plant in the 2013-2014, 2015-2016 growing seasons; burclover was tested in 2014-2015. An eight-field crop rotation system was used.

Sowing was postponed for three weeks due to adverse weather in 2015-2016. The total area of each option was $500 \mathrm{~m}^{2}$. The winter wheat variety Kalym was used (mid-season, semi-dwarf, highly resistant to lodging, leaf rust, septoria, and powdery mildew). This variety had a medium resistance to $P$. tritici-repentis $\mathrm{Kr}-15 / 2016$ (the incidence rate was up to $30 \%$ ) and is widespread in the Kuban region.

The neighboring experimental plots with a large amount of plant residues were the primary source of infection. In addition, the weather contributed to its spread. As the plants grew, the infection intensity increased due to both expansion of the previously infected spots and the appearance of the new ones. This indicates re-infection during the season.

Seeds were treated before sowing; vegetative plants were treated twice. The liquid crop application rate of BZR $336 \mathrm{~g}$ and BZR 517 was 3 and $2 \mathrm{~L} / \mathrm{t}$ respectively for seed treatment; and 3 and $2 \mathrm{~L} /$ ha for spraying plants. The working fluid consumption was $10 \mathrm{~L} / \mathrm{t}$ and $300 \mathrm{~L} / \mathrm{ha}$. In the control, the seeds were treated with tap water. Sowing was carried out with a mechanical seeder SZN-3.6 (Russia). The seeding rate was $220 \mathrm{~kg} / \mathrm{ha}$, with row spacing of $15 \mathrm{~cm}$. The grain was treated with a manual sprayer and mixed manually using agricultural equipment; the plants were treated with a mounted boom sprayer. 
We applied Stomp herbicide, CE (pendimetalin, $330 \mathrm{~g} / \mathrm{L}$ ) at a rate of $4.5 \mathrm{~L} /$ ha prior to the emergence of plant shoots. In the spring, the herbicide Prima SE $(300 \mathrm{~g} / \mathrm{L} 2,4-\mathrm{D}$ (2-ethylhexyl ether) $+6.25 \mathrm{~g} / \mathrm{L}$ florasulam) was used at an application rate of $0.6 \mathrm{~L} / \mathrm{ha}$ in the tillering phase.

The severity of leaf disease was evaluated sequentially as it spreads. We visually assessed the leaf damage area as a percentage to the total leaf area in the tillering phase in autumn (Z 20-21) and spring (Z 26-21) at the shooting stage (Z 32-35) and at maturation (Z 73-77). The data in the table were obtained at the maximum development of the disease. We applied Abbott's formula to calculate biological efficiency [31].

\subsection{Statistical Analysis}

All experiments were performed in triplicate. We ran Duncan's Multiple Range Test in STATISTICA 13.2 EN (trial version, Tibco, Palo Alto, CA, USA).

\section{Results}

\subsection{Study Design}

The research work consisted of laboratory studies (analysis and microscopy of dual cultures), studies in a climatic chamber of artificial infection under controlled conditions, and three-year field trials of natural infection.

\subsection{Laboratory Experiments}

The in vitro strains BZR $336 \mathrm{~g}$ and BZR 517 exhibited good antagonistic properties against $P$. tritici-repentis $\mathrm{Kr}-15 / 2016$. Maximum growth suppression of the pathogen mycelium reached $93.9 \%$. BZR $336 \mathrm{~g}$ in high mobility provided a noticeable antifungal effect (81.8-94.3\%). This resulted in the rapid decrease of the sterile area. The B. velezensis BZR 517 strain did not show such mobility. Its antifungal activity ranged from 57.6 to $72.4 \%$. However, this strain retained the sterile area for a long time (Table 2, Figure 2).

Table 2. Antifungal activity of BZR $336 \mathrm{~g}$ and BZR 517 against P. tritici-repentis $\mathrm{Kr}-15 / 2016$ (the dual culture method).

\begin{tabular}{|c|c|c|c|c|}
\hline \multirow[t]{2}{*}{ Co-Cultivation Options } & \multicolumn{2}{|c|}{ The Growth of Mycelium from the Seed Block, mm } & \multicolumn{2}{|c|}{ Inhibition of Mycelium Growth, $\%$} \\
\hline & 5th Day & 15th Day & 5th Day & 15th Day \\
\hline $\begin{array}{l}\text { Control (P. tritici-repentis } \\
K r-15 / 2016)\end{array}$ & $13.2^{\mathrm{c}}$ & $60.9^{c}$ & - & - \\
\hline BZR $336 \mathrm{~g}$ & $2.4^{b}$ & $3.5^{\mathrm{a}}$ & 81.8 & 94.3 \\
\hline BZR 517 & $5.6^{\mathrm{a}}$ & $16.8^{\mathrm{b}}$ & 57.6 & 72.4 \\
\hline
\end{tabular}

Note: Different letters indicate significant differences $(p<0.05)$ according to Duncan's test.

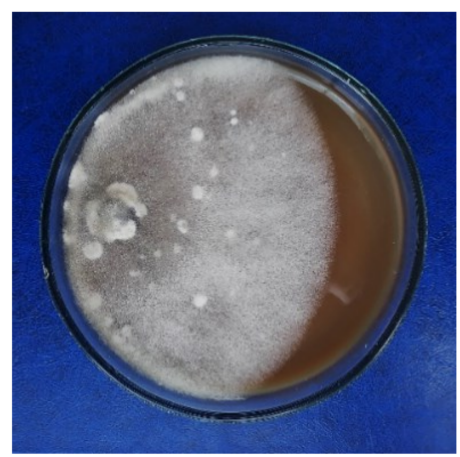

(a)

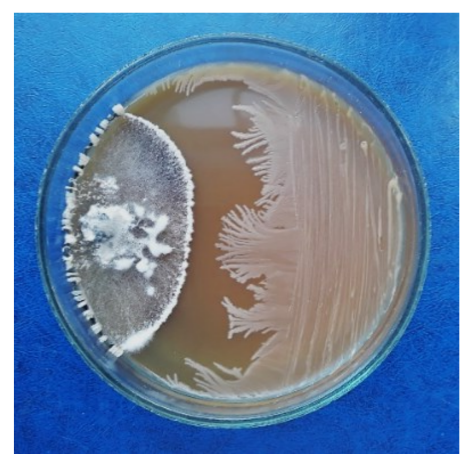

(b)

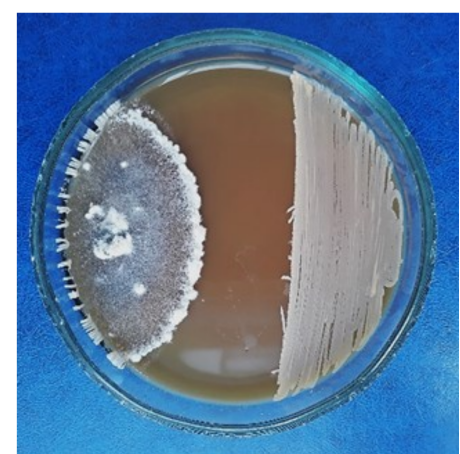

(c)

Figure 2. Dual cultures of $P$. tritici-repentis $\mathrm{Kr}-15 / 2016$ and antagonistic strains: (a) control without an antagonist, (b) together with BZR $336 \mathrm{~g}$, (c) together with BZR 517; seven days of co-cultivation. 
P. tritici-repentis mycelium segments were shortened by 2.5-4 times and thickened by 2-2.5 times compared with the control on the third day of joint cultivation with the strains BZR $336 \mathrm{~g}$ and BZR 517. The growth mycelium in terms of length was noticeably inhibited, and its branching increased (Figure 3).

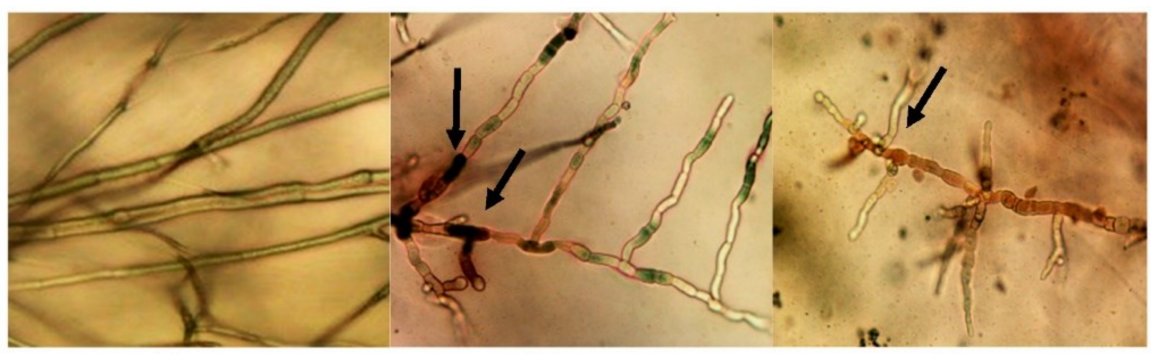

(a)

(b)

(c)

Figure 3. Hyphae of $P$. tritici-repentis $\mathrm{Kr}-15 / 2016$ : in control without an antagonist (a); after three days of co-cultivation with B. velezensis BZR $336 \mathrm{~g}$ (b) and BZR 517 (c), arrows show the pigmentation of hyphae; $\times 200$ magnification.

We observed "vacuolization" (the formation of large membranous vesicles) in the cytoplasm of pathogen hyphae on the 3rd-7th day of BZR $336 \mathrm{~g}$ strain fungus cultivation (Figure 4).

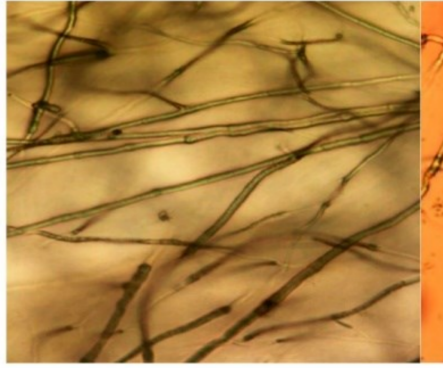

(a)

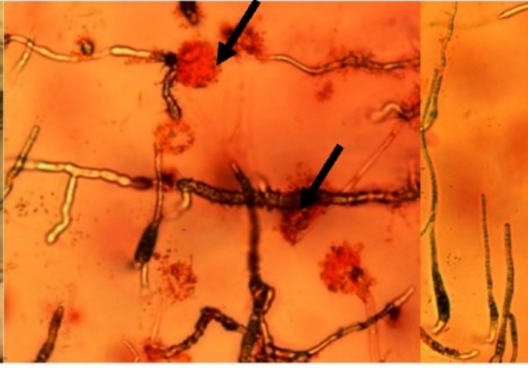

(b)

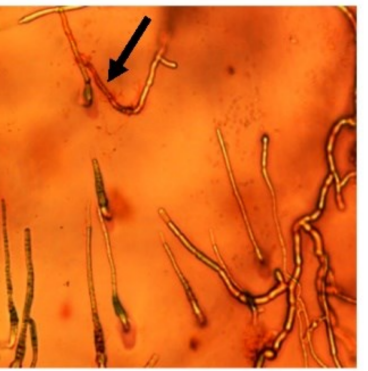

(c)

Figure 4. P. tritici-repentis $\mathrm{Kr}-15 / 2016$ hyphae: control (a); and vacuolization of hyphae after 3 days of co-cultivation with strain BZR $336 \mathrm{~g}$ (b) and on the seventh day of co-cultivation with strain 517 (c); $\times 400$ magnification.

On the 7-10th day, the pathogen mycelium broke up into separate fragments releasing the pigmented hyphae content. We observed a similar process at BZR 517 strain cultivation, though with a delay of three to four days (Figure 5).

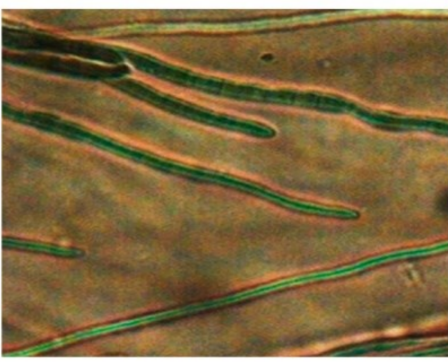

(a)

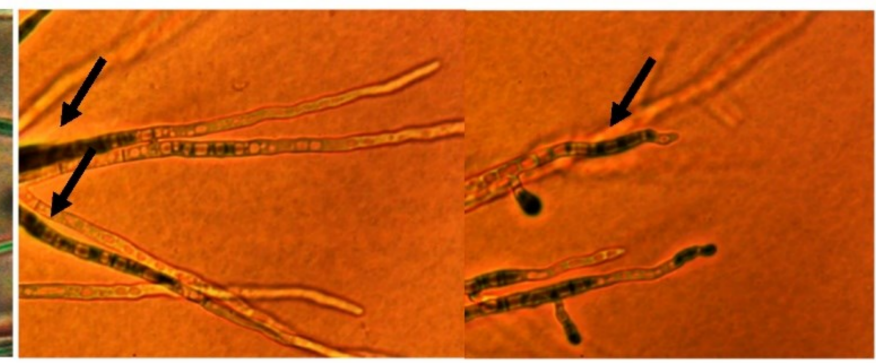

(b) (c)

Figure 5. Hyphae of P. tritici-repentis Kr-15/2016: control (a); decomposition of mycelium during co-cultivation with strain BZR $336 \mathrm{~g}$ on day 10 (b), and with 517 strain on day 14 of co-cultivation (c). Arrows show the areas with the release of pigmented hyphae contents; magnification $\times 200$. 
We did not register direct contact between the fungus and bacteria. Nevertheless, we noted a chemotaxis of BZR $336 \mathrm{~g}$ bacterial cells towards the fungal hyphae, after which the hyphae completely dissolved. BZR 517 cell movement was insignificant or absent.

\subsection{Growth Chamber Assay}

Two criteria determined the biological efficiency: (1) the number of infection points (bioagent ability to suppress the penetration of the pathogen into the plant); (2) type of resistance (bioagent ability to control an infection which has already penetrated the plant tissue). The biological efficiency of the liquid culture based on BZR $336 \mathrm{~g}$ with seed treatment was $38.4 \%$ in terms of reducing the number of foci of infection and $50.8 \%$ in terms of resistance type. It was 10 and $38 \%$ higher than when only treating the plants (Table 3 ).

Table 3. Biological efficacy (BE, \%) of strains BZR $336 \mathrm{~g}$ and BZR 517 against P. tritici-repentis $\mathrm{Kr}-15 / 2016$ under conditions of artificial inoculation of winter wheat Batko in the climatic chamber.

\begin{tabular}{|c|c|c|c|c|c|}
\hline & & \multicolumn{4}{|c|}{ Methods of Treatment } \\
\hline & & Control & Chemical Treatment & BZR $336 \mathrm{~g}$ & BZR 517 \\
\hline \multirow{4}{*}{ Seed and plant treatment } & the number of infection points & $2.37^{b}$ & $0.44^{\mathrm{c}}$ & $1.48^{\mathrm{a}}$ & $1.63^{\mathrm{ab}}$ \\
\hline & type of sustainability, score & 1.85 be & $0.63^{\mathrm{ab}}$ & $0.91^{\mathrm{cd}}$ & $1.48^{\mathrm{ab}}$ \\
\hline & $\begin{array}{l}\text { BE by the number of infection } \\
\text { points, } \%\end{array}$ & 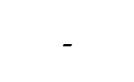 & 81.4 & 38.4 & 31.2 \\
\hline & BE by of sustainability, \% & - & 65.9 & 50.8 & 20.0 \\
\hline \multirow{4}{*}{ Plant treatment } & the number of infection points & $5.25^{b}$ & $1.40^{\mathrm{C}}$ & $3.76^{\mathrm{a}}$ & $2.95^{\mathrm{a}}$ \\
\hline & type of sustainability, score & $2.55^{\mathrm{ac}}$ & $1.03^{b}$ & $2.22^{\mathrm{a}}$ & $1.40^{b}$ \\
\hline & $\begin{array}{l}\text { BE by the number of infection } \\
\text { points, } \%\end{array}$ & - & 73.3 & 28.4 & 43.8 \\
\hline & BE by of sustainability, \% & - & 59.6 & 12.9 & 45.1 \\
\hline
\end{tabular}

Note: Different letters indicate significant differences $(p<0.05)$ according to Duncan test.

A liquid culture based on the BZR $336 \mathrm{~g}$ strain turned out to be more effective in the treatment of seeds and plants- $50.8 \%$ in terms of resistance type and $38.4 \%$ in terms of infection points. Efficiency was lower when treating only plants. In turn, the liquid culture based on the BZR 517 strain proved to be highly effective only for plant treatment: $43.8 \%$ in terms of infection points and $45.1 \%$ in terms of resistance type. When seeds were treated with this strain, its efficiency decreased by $13-25 \%$ (Table 3 ). The effectiveness of the standard in the treatment of seeds and plants was high: $81.4 \%$ by the number of infection points and $65.9 \%$ in terms of resistance type $(p=0.05)$. However, these figures were only $6-8 \%$ higher than when treating plants alone.

\subsection{Field Trials}

The incidence rate of tan spot in the control was 3.3\% in the growing season of 2013-2014. A statistically significant reduction in the severity of the disease was observed when using B. velezensis BZR $336 \mathrm{~g}$, B. velezensis BZR 517 and a chemical standard $(p<0.05)$. The standard proved the highest efficiency of $83.1 \%$ (Table 4 ).

The severity of tan spot was 7.5\%. In the growing season of 2014-2015, all experiments registered a statistically significant reduction in the incidence rate $(p=0.05)$. The biological efficiency of the strains was $41.8-43.6 \%$. The effectiveness of the chemical standard was $83.7 \%$ (Table 4 ).

In 2015-2016, the incidence rate was 7.6\%. All experiments registered a statistically significant reduction of the tan spot rate $(p=0.05)$. The liquid culture efficiency for BZR $336 \mathrm{~g}$ was $50.0 \%$ and for BZR 517 it was $34.2 \%$. The biological effectiveness of chemical fungicide was $65.7 \%$ (Table 4 ). 
Table 4. Biological efficacy (BE, \%) and yield of winter wheat of Kalym cultivar treated with the strains BZR $336 \mathrm{~g}$ and BZR 517 under stationary crop rotation, 2013-2016.

\begin{tabular}{ccccc}
\hline & Methods of Treatment & Severity, \% & BE, \% & Yield, t/ha \\
\hline & Control & $3.3^{\mathrm{d}}$ & - & $6.9^{\mathrm{a}}$ \\
$2013-2014$ & Chemical treatment & $0.6^{\mathrm{c}}$ & 83.1 & $7.0^{\mathrm{a}}$ \\
& BZR 336 g & $2.0^{\mathrm{ab}}$ & 49.2 & $7.2^{\mathrm{c}}$ \\
& BZR 517 & $1.7^{\mathrm{ab}}$ & 38.5 & $7.6^{\mathrm{b}}$ \\
\hline \multirow{2}{*}{$2014-2015$} & Control & $7.5^{\mathrm{b}}$ & - & $6.0^{\mathrm{a}}$ \\
& Chemical treatment & $1.2^{\mathrm{c}}$ & 83.7 & $7.1^{\mathrm{ab}}$ \\
& BZR 336 g & $4.4^{\mathrm{a}}$ & 41.8 & $7.4^{\mathrm{b}}$ \\
& BZR 517 & $4.2^{\mathrm{a}}$ & 43.6 & $7.1^{\mathrm{ab}}$ \\
\hline \multirow{2}{*}{$2015-2016$} & Control & $7.6^{\mathrm{b}}$ & - & $5.2^{\mathrm{ab}}$ \\
& Chemical treatment & $2.6^{\mathrm{a}}$ & 65.7 & $5.6^{\mathrm{c}}$ \\
& BZR 336 g & $3.8^{\mathrm{a}}$ & 50.0 & $5.0^{\mathrm{a}}$ \\
& BZR 517 & $5.0^{\mathrm{a}}$ & 34.21 & $5.5^{\mathrm{bc}}$ \\
\hline
\end{tabular}

Note: Different letters indicate significant differences $(p<0.05)$ according to Duncan's test.

Both in 2013-2014 and 2014-2015 the yield in the control was approximately the same (6.9-6.0 $\mathrm{t} / \mathrm{ha}$ and 6.4-7.4 $\mathrm{t} / \mathrm{ha}$, respectively). We recorded a statistically significant increase in yield above the chemical standard using BZR $336 \mathrm{~g}$ (7.2 t/ha in 2014 and $7.3 \mathrm{t} / \mathrm{ha}$ in 2015) and BZR 517 (7.6 t/ha in 2014 and 7.1 t/ha in 2015) (Table 4).

We had the lowest yield in 2015-2016 as a result of shifting the planting dates by three weeks due to unfavorable weather. In the control it was $5.2 \mathrm{t} / \mathrm{ha}$. Only the standard indicated a statistically significant $(5.7 \mathrm{t} / \mathrm{ha})$ increase in yield compared to the control (Table 3).

\section{Discussion}

Biological control is a promising plant pathogen control strategy. The findings of previous studies confirm the effectiveness of antagonistic microorganisms as control phytopathogens $[3,6,10,11,16,32]$.

Several studies consider the interaction of $P$. tritici-repentis with antagonistic PGPR [6,10,11,16,32]. Larran et al. [10] showed that endophytic microorganisms isolated from wheat, including Bacillus sp., proved to be effective biocontrol agents for P. tritici-repentis. They suppressed the growth of pathogens, reduced the diameter of fungal colonies, the percentage of spore germination in the laboratory, and disease severity in the greenhouse. Microscopic examination revealed degenerative changes in the mycelium of pathogenic microorganisms during co-incubation with isolates of bacteria and fungi. Researchers observed conidial plasmolysis, shortening and swelling of germ tubes, hyphae vacuolization, induced chlamydospore formation, and production of pigmented compounds within hyphae or in the culture medium [10].

In Perello et al. [6], bioagents for pre-sowing seed/vegetative plants treatment reduced the incidence of tan spot from 16 to $56 \%$. Syrian researchers studied the effect of promising strains on susceptibility to tan spot in barley varieties differing in resistance to P. graminea. They proved a significant increase in plant resistance [11]. Pfender et al. [32] described the reduction of primary inoculum of a phytopathogen in surface crop residues when microbial bioagents were applied.

This paper is a part of a comprehensive study of the effect of bacterial strains BZR $336 \mathrm{~g}$ and BZR 517 against winter wheat diseases. Previously, we used these strains to control Fusarium root rot disease, but then we discovered that they are effective against leaf diseases as well [18,33].

Here we found that B. velezensis strains BZR $336 \mathrm{~g}$ and BZR 517 showed antagonistic activity against $P$. tritici-repentis in vitro and caused degenerative changes to the pathogen mycelium. We assume that BZR $336 \mathrm{~g}$ possesses a MOA based on active mobility, while 
BZR 517 is based on active production of antifungal metabolites. Future research will need to clarify what classes these substances belong to.

We concluded that BZR $336 \mathrm{~g}$ and BZR 517 were effective against $P$. tritici-repentis in a climate chamber. Two criteria determined biological efficacy: (1) bioagent ability to suppress the penetration of the pathogen into the plant; and (2) bioagent ability to control an infection which has already penetrated the plant tissue [30]. The biological efficiency of the treatment of seeds and plants with BZR $336 \mathrm{~g}$ was 10\% higher than when treating the plants alone. In turn, BZR 517 proved to be highly effective only in plant treatment. Presumably the reason lies in different MOA of strains on the pathogen.

We conclude that the sequential treatment of seeds and plants is most effective. A. Perello [6] and W.C. Luz [16] described the method of seed treatment with microorganisms to control $P$. tritici-repentis. The authors assumed that seed treatment is most effective in reducing the incidence of tan spot. Apparently, this treatment causes systemic resistance responses in plants.

In our study, biological efficiency did not correlate with yield. For example, in 2013-2014 the protective effect of BZR $336 \mathrm{~g}$ and BZR 517 on plants was lower than that of the chemical fungicide (standard). However, the additional yield was higher than in the standard. The yield in the control was $6.9 \mathrm{t} / \mathrm{ha}$.

In 2015-2016, we received low yields on the field, as a result of shifted planting dates due to unfavorable weather. A statistically significant increase in yield compared to the control was obtained only when using the chemical standard (5.6 t/ha) (Table 3). Our results prove that living microorganisms are very sensitive to environmental conditions; therefore, strict adherence to agrotechnological measures is necessary.

\section{Conclusions}

The outcome indicates that $B$. velezensis strains are effective bioagents against P. tritici-repentis. The B. velezensis strains BZR $336 \mathrm{~g}$ and BZR 517 exhibited antagonistic activity against $P$. tritici-repentis $\mathrm{Kr}-15 / 2016$ in vitro: they inhibited the mycelium growth by $72.4-94.3 \%$ and caused its degenerative changes. The results of the experiment clearly show that the treatment of wheat plants with strains $B$. velezensis resulted in a reduction in the development of infection in the climatic chamber and in the field. The use of BZR $336 \mathrm{~g}$ and BZR 517 in a three-year field trial provided 5.0-7.6\% additional yield. Our studies confirm that BZR $336 \mathrm{~g}$ and BZR 517 have both fungicidal and growth-promoting properties. Consequently, they can be used for preventive treatments of agricultural plants. BZR $336 \mathrm{~g}$ and BZR 517 are promising for organic farming where chemical fungicides are prohibited. However, it is necessary to more carefully observe the necessary agrotechnical measures when using living means of biocontrol.

\section{Patents}

Asaturova A.M., Tomashevich N.S., Zhevnova N.A., Homyak A.I., Dubyaga V.M., Pavlova M.D., Kozitsyn A.E., Sidorova T.M. “Biofungicide for protecting crops from diseases and increasing yields" / Patent for invention RUS 26213563 December 2015.

Author Contributions: Conceptualization, A.A., N.Z., N.T., O.K. and G.V.; methodology, N.Z. and O.K.; validation, A.A. and O.K.; formal analysis, N.T. and N.Z.; investigation, M.P. and N.S.; resources, M.P. and N.S.; data curation, N.T. and N.Z.; writing—original draft preparation, N.Z.; writing-review and editing, A.A.; visualization, A.A.; project administration, A.A. and G.V.; funding acquisition, A.A. and G.V. All authors have read and agreed to the published version of the manuscript.

Funding: The research was carried out in accordance with the State Assignment of the Ministry of Science and Higher Education of the Russian Federation within the framework of research on the topic No FGRN-2022-0006 «Development of technologies for integrated protection of agricultural crops, taking into account the immunological characteristics of the variety».

Institutional Review Board Statement: Not applicable.

Informed Consent Statement: Not applicable. 
Acknowledgments: We express our gratitude to Aleksan Albertovich Khalafyan for statistical data processing.

Conflicts of Interest: The authors declare that they have no conflict of interest.

\section{References}

1. Moreno, M.V.; Stenglein, S.A.; Perello, A.E. Pyrenophora tritici-repentis, causal agent of tan spot: A review of intraspecific genetic diversity. In The Molecular Basis of Plant Genetic Diversity; InTech: London, UK, 2012; pp. 297-330.

2. Bertagnolli, V.V.; Ferreira, J.R.; Liu, Z.H.; Rosa, A.C.; Deuner, C.C. Phenotypical and genotypical characterization of Pyrenophora tritici-repentis races in Brazil. Eur. J. Plant Pathol. 2019, 154, 995-1007. [CrossRef]

3. Lamari, L.; Strelkov, S. Minireview/Minisynthese. The wheat/Pyrenophora tritici-repentis interaction: Progress towards an understanding of tan spot disease. Can. J. Plant Pathol. 2010, 32, 4-10. [CrossRef]

4. Hosford, R.M. Tan spot. In Tan Spot of Wheat and Related Diseases; North Dakota State University: Fargo, ND, USA, $1982 ;$ pp. 1-24.

5. Francl, L.J. Local and mesodistance dispersal of Pyrenophora tritici-repentis conidia. Can. J. Plant Pathol. $2009,3,247-255$.

6. Perello, A.; Moreno, V.; Mónaco, C.; Simón, M.R. Effect of Trichoderma spp. isolates for biological control of tan spot of wheat caused by Pyrenophora tritici-repentis under field conditions in Argentina. Biocontrol 2008, 53, 895-904. [CrossRef]

7. Abdullah, S.; Sehgal, S.; Ali, S. Race diversity of Pyrenophora tritici-repentis in South Dakota and response of predominant wheat cultivars to tan spot. J. Plant Pathol. Microbiol. 2017, 8, 409.

8. Kamel, S.; Cherif, M.; Hafez, M.; Despins, T.; Aboukhaddour, R. Pyrenophora tritici-repentis in Tunisia: Race structure and effector genes. Front. Plant Sci. 2019, 10, 1562. [CrossRef]

9. Kremneva, O.Y.; Volkova, G.V.; Kovalenko, N. The dynamics of the race structure of Pyrenophora tritici-repentisin the North Caucasus region. Mikol. I Fitopatol. 2019, 53, 246-253.

10. Larran, S.S.; Simón, M.R.; Moreno, M.V.; Perello, A. Endophytes from wheat as biocontrol agents against tan spot disease. Biol. Cont. 2016, 92, 17-23. [CrossRef]

11. Adam, A.; Arabi, M.I.E.; Idris, I.; Al-Shehadah, E. Effect of several rhizobacteria strains on barley resistance against Pyrenophora graminea under field conditions. Hell. Plant Protect. J. 2017, 10, 35-45. [CrossRef]

12. Ciuffetti, L.; Manning, V.; Pandelova, I.; Faris, J.; Friesen, T.; Strelkov, S.; Weber, G.; Goodwin, S.; Wolpert, T.; Figueroa, M Pyrenophora tritici-repentis: A plant pathogenic fungus with global impact. In Genomics of Plant-Associated Fungi: Monocot Pathogens; Springer: Berlin/Heidelberg, Germany, 2014.

13. Kremneva, O.Y.; Mironenko, N.V.; Volkova, G.V.; Baranova, O.A.; Kim, Y.S.; Kovalenko, N.M. Resistance of winter wheat varieties to tan spot in the North Caucasus region of Russia. Saudi J. Bio. Sci. 2021, 28, 1787-1794. [CrossRef] [PubMed]

14. Mehamdiaa, D.; Meradb, T.; Tichatia, L. Triazole and strobilurin fungicides sensitivity of Pyrenophora tritici-repentis isolates originated from eastern Algeria. Mycol. Phytopathol. 2020, 3, 221-227. [CrossRef]

15. Knorr, K.; Jørgensen, L.N.; Nicolaisen, M. Fungicides have complex effects on the wheat phyllosphere mycobiome. PLoS ONE 2019, 14, e0213176. [CrossRef] [PubMed]

16. Luz, W.C. Seed Microbiolization of Wheat to Control Drechslera Tritici-Repentis; Krupinsky, L.J., McMullen, M.P., Eds.; North Dakota Agricultural Experiment Station: Fargo, ND, USA, 1994; pp. 65-67.

17. Raaijmakers, J.M.; Bruijn, L.; Nybroe, O.; Ongena, M. Natural functions of lipopeptides from Bacillus and Pseudomonas: More than surfactants and antibiotics. FEMS Microbiol. Rev. 2010, 34, 1037-1062. [CrossRef] [PubMed]

18. Asaturova, A.M.; Tomashevich, N.S.; Zhevnova, N.A.; Krivoshlykov, K.M.; Khomyak, A.I. Ecological system of wheat protection based on new original biofungicides. Taurian Newsl. Agrar. Sci. 2019, 1, 31-42.

19. Shternshis, M.; Asaturova, A.; Shpatova, T.; Maslennikova, V.; Zhevnova, N.; Homyak, A. Promising Bacillus subtilis strains BZR $336 \mathrm{~g}$ and BZR 517 for biocontrol of blackcurrant against Septoria leaf spot under unfavorable climate conditions. J. Plant Pathol. 2021, 103, 295-298. [CrossRef]

20. Asaturova, A.; Shternshis, M.; Tsvetkova, V.; Shpatova, T.; Maslennikova, V.; Zhevnova, N.; Homyak, A. Biological control of important fungal diseases of potato and raspberry by two Bacillus velezensis strains. Peer J. 2021, 9, e11578. [CrossRef] [PubMed]

21. Garkovenko, A.V.; Ilnitskaya, E.V.; Radchenko, V.V.; Milovanov, A.V.; Vasilyev, I.Y.; Grigoreva, T.V.; Asaturova, A.M.; Kozitsyn, A.E.; Tomashevich, N.S.; Shternshis, M.V. Draft genome sequence of Bacillus velezensis BZR 336 g, a plant growth-promoting antifungal biocontrol agent isolated from winter wheat. Microbiol. Resour. Announc. 2020, 9, e00853-20. [CrossRef]

22. Milovanov, A.V.; Asaturova, A.M.; Tomashevich, N.S.; Kozitsyn, A.E.; Shternshis, M.V. Initial analysis of the results of genomewide sequencing of biocontrol strains Bacillus subtilis BZR $336 \mathrm{~g}$ and Bacillus subtilis BZR 517. Proc. Kuban State Agrar. Univ. 2019, 81, 131-137. [CrossRef]

23. Lamari, L.; Bernier, C.C. Evaluation of wheat lines and cultivars to tan spot [Pyrenophora tritici-repentis] based on lesion type. Can. J. Plant Pathol. 1989, 11, 49-56. [CrossRef]

24. Lamari, L.; Strelkov, S.E.; Yahyaoui, A.; Orabi, J.; Smith, R.B. The identification of two new races of Pyrenophora tritici-repentis from the host center of diversity confirms a one-to-one relationship in tan spot of wheat. Phytopathology 2003, 93, 391-396. [CrossRef] [PubMed]

25. Singh, P.K.; Singh, R.P.; Duveiller, E.; Mergoum, M.; Adhikari, T.B.; Elias, E.M. Genetics of wheat-Pyrenophora tritici-repentis interactions. Euphytica 2009, 171, 1-13. [CrossRef] 
26. Kremneva, O.Y.; Asaturova, A.M.; Zharnikova, M.D.; Volkova, G.V. The strains of bacteria-antagonists of Pyrenophora tritici-repentis in vitro, effective against wheat yellow leaf spot in the seedling phase in the growing experiment. Agric. Biol. 2015, 1, 99-106.

27. Asaturova, A.M.; Homyak, A.I.; Tomashevich, N.S.; Pavlova, M.D.; Zhevnova, N.A.; Dubyaga, V.M.; Kozitsin, A.Y.; Sidorova, T.M.; Nadykta, V.D.; Ismailov, V.Y. Conditions for the cultivation of new bacillus bacteria being micro bioproduct producers. J. Pure Appl. Microbiol. 2015, 4, 2797-2804.

28. Montealegre, J.R. Selection of bioantagonistic bacteria to be used in biological control of Risoctonia solani in tomato. Elec. J. Biotechnol. 2003, 6, 116-127. [CrossRef]

29. Huang, H.C.; Hoes, J.A. Penetration and infection of Sclerotinia sclerotiorum by Coniothyrium minitans. Can. J. Bot. 1976, 54, 406. [CrossRef]

30. Rees, R.G.; Platz, G.J.; Mayer, R.J. Susceptibility of Australian wheats to Pyrenophora tritici-repentis. Aust. J. Agric. Res. 1988, 39, 141-151. [CrossRef]

31. Abbott, W.S. A method of computing the effectiveness of an insecticide. J. Econ. Entomol. 1925, 2, 265-267. [CrossRef]

32. Pfender, W.F.; Zhang, W.; Nus, A. Biological control to reduce inoculum of the tan spot pathogen Pyrenophora tritici-repentis in surface-borne residues of wheat fields. Phytopathology 1933, 4, 371-375.

33. Sidorova, T.M.; Asaturova, A.M.; Homyak, A.I.; Tomashevich, N.S. Isolation and characterization of antifungal metabolites of Bacillus subtilis strains BZR $336 \mathrm{~g}$ and BZR 517 using the modified bioauthography method. Agric. Biol. 2019, 1, 178-185. [CrossRef] 